\title{
ARTICLE
}

\section{Who'll Stop the Rain? Allocating Emissions Allowances for Free: Environmental Policy, Economics, and WTO Subsidy Law}

\author{
Luca Rubini* and Ingrid Jegou**
}

First published online 13 September 2012

\begin{abstract}
This article investigates the environmental and economic impact of the free allocation of emissions allowances in Emissions Trading Schemes (ETSs) as well as its compatibility with trade law. Free allocation can facilitate the industry's gradual adjustment to an ETS and hence boost its acceptability. At the same time, however, the article shows that the economic and environmental benefits of free allocation are debatable. Moreover, the practice of free allocation possibly contravenes WTO law. The conclusion that free allowances may constitute an objectionable subsidy under WTO subsidy disciplines raises questions of law reform. Should the ETS be reformed to fit conventional trade imperatives, or should trade law be rethought so as to be responsive to contemporary environmental protection strategies? The article argues that, considering the questionable benefits of free allocation, any adjustment to trade law should be narrow and temporary.
\end{abstract}

Keywords: Emissions Trading Scheme (ETS), Emissions Allowances, Free Allocation, Environmental and Economic Analysis, World Trade Organization, WTO Subsidy Law, Climate Change

* Institute of European Law, Birmingham Law School, United Kingdom.

Email: 1.rubini@bham.ac.uk.

** Global Platform on Climate Change, Trade and Sustainable Energy, International Centre for Trade and Sustainable Development (ICTSD), Geneva, Switzerland.

Email: ijegou@ictsd.ch.

This article draws on I. Jegou \& L. Rubini, 'The Allocation of Emission Allowances Free of Charge: Legal and Economic Considerations', International Centre for Trade and Sustainable Development (ICTSD), Issue Paper 18/2011, Programme on Competitiveness and Sustainable Development, Geneva (Switzerland), Aug. 2011, available at: http://ictsd.org/downloads/2011/11/the-allocation-of-emissionallowances-free-of-charge.pdf. Ingrid Jegou is mainly responsible for Parts 2 and 3 of the article, Luca Rubini for Part 4. The introduction and conclusions are joint efforts. The authors are grateful to the ICTSD for initiating and supporting this research. They thank Petros Mavroidis, Robert Howse, Vangelis Vitalis, John Stephenson, Samantha Derksen and Marie Wilke for their valuable review and comments. They also wish to thank Ricardo Meléndez-Ortiz and Peter Wooders for helpful discussions and input, as well as the anonymous reviewers for their helpful comments. 'Who'll Stop the Rain' is a song by Credence Clearwater Revival, from their 1970 album, Cosmo's Factory. 


\section{INTRODUCTION}

Emissions trading schemes (ETSs) form a common policy measure intended to reduce emissions in a cost-effective manner. The most popular and large-scale greenhouse gas (GHG) scheme is certainly that deployed by the European Union (EU), ${ }^{1}$ but significant examples can be found in countries such as Norway, ${ }^{2}$ Switzerland $^{3}$ or New Zealand, ${ }^{4}$ or in sub-national and regional contexts, such as Tokyo (Japan) ${ }^{5}$ or the Regional Greenhouse Gas Initiative (RGGI) ${ }^{6}$ in North America. ${ }^{7}$

An ETS consists of three main elements: (i) a cap for total emissions from covered sectors (or a restriction of emissions related to a pre-specified level of inputs or outputs); (ii) rights or 'allowances' to emit GHGs; and (iii) a market for trading the allowances. The cost-effectiveness of the scheme relates to the incentives purposely created to cash in on one's own efficiency in reducing emissions: reductions can be undertaken where the abatement costs are relatively low, whereas industries with less favourable abatement opportunities can buy additional allowances on the market.

The fundamental difference between an ETS and any conventional market is that the amount of allowances available depends directly on governmental decisions. A central authority estimates emissions for a specific period of time, sets an overall cap or an intensity-target below that level, divides this into individual emissions quotas and distributes corresponding allowances to each trading entity participating in the scheme.

It is extremely common, at least in the initial phases of an ETS, for emissions allowances to be allocated, in total or in large part, free of charge. There are several reasons for this. Introducing a scheme for charging polluters is difficult as it implies costs for the domestic industry, important actors for domestic growth and employment. Initially distributing allowances free of charge is a way of introducing the costs gently, so as to allow the firms to adjust gradually to the new policy environment before the administrator moves to other modes of distribution, such as auctioning. This not only protects the industry from an overly abrupt change in the conditions

1 European Commission, Climate Action, ‘Emissions Trading System (EU ETS)', available at: http://ec.europa. eu/clima/policies/ets/index_en.htm.

2 Ministry of the Environment (Norway), 'Norwegian National Allocation Plan for the Emissions Trading System in 2008-2010', available at: http:/www.regjeringen.no/en/dep/md/documents-andpublications/reports-and-plans/Plans/2008/norwegian-national-allocation-plan-for-t.html?id=505229.

3 Federal Office for the Environment (Switzerland), 'Emissions Trading in Switzerland', available at: http://www.bafu.admin.ch/emissionshandel/05538/05540/index.html?lang=en.

4 Climate Change Information (New Zealand), 'The New Zealand Emissions Trading Scheme', available at: http://www.climatechange.govt.nz/emissions-trading-scheme.

5 Tokyo Metropolitan Government, Bureau of the Environment, 'Tokyo Cap-and-Trade Program: Japan's First Mandatory Emissions Trading Scheme, Mar. 2010, available at: http://www.kankyo. metro.tokyo.jp/en/attachement/Tokyo-cap_and_trade_program-march_2010_TMG.pdf.

6 See http://www.rggi.org.

7 For an overview of some of these schemes, see I. Jegou \& L. Rubini, 'The Allocation of Emission Allowances Free of Charge: Legal and Economic Considerations', International Centre for Trade and Sustainable Development (ICTSD), Issue Paper 18/2011, Programme on Competitiveness and Sustainable Development, Geneva (Switzerland), Aug. 2011, available at: http://ictsd.org/downloads/2011/11/ the-allocation-of-emission-allowances-free-of-charge.pdf. 
under which it operates, but also contributes to fostering acceptance of the scheme. Other reasons relate to concerns of carbon leakage and distortions in competitiveness. Carbon leakage refers to the possibility that a unilateral introduction of a carbon cost will negatively affect the competitive position of the domestic industry in favour of firms in countries without a similar carbon cost. Leakage occurs when, following regulation, emissions are reduced in one country, but are then increased elsewhere as a result of a relocation of the polluting activity. ${ }^{8}$

The practice of allocating emissions allowances free of charge raises important questions. For instance, does free allocation dilute the incentives to reduce GHG emissions which the ETS should bring about, and is it effective as an instrument to mitigate competitiveness or carbon leakage concerns? What are the subsidy effects that this free transfer may have on international trade and competition? This article seeks to answer these questions on the basis of an economic and legal analysis, with a special focus on World Trade Organization (WTO) law. From a different perspective, this article mainly poses a question of policy space. How much autonomy do WTO rules offer to Members in granting free allowances? Is this sufficient? If not, is law reform necessary? And, if so, what are the key guidelines to which it should adhere?

The question of whether the free allocation of allowances constitutes a subsidy is also a good case study for outlining some of the features of contemporary problems in environmental and trade governance, characterized by the novelty of the policy tools and complexity of policy choices, the paucity of empirical data and the intricacy of the legal issues.

\section{THE EFFECT(IVENESS) OF FREE ALLOWANCES}

Free allowances are a handy tool for policy-makers. As environmental measures go, they are generally attractive to the industry and, although they constitute an opportunity cost to the government, they do not involve direct expenditure. At the same time, however, the difference in government revenue from granting allowances free of charge or requiring emitters to purchase them can be extremely large. ${ }^{9}$ The question of whether the free allocation of allowances is an efficient use of resources is therefore legitimate.

\subsection{Are Free Allowances Effective in Reducing GHGs?}

It is not the free allocation in itself that can reduce emissions but the carbon cost imposed through an ETS. An ETS may create incentives for reducing emissions, both

8 As of today, there is limited empirical evidence of carbon leakage: for a summary of empirical findings, see P. Wooders \& A. Cosbey, 'Climate-Linked Tariffs and Subsidies: Economic Aspects (Competitiveness and Leakage)', Background Paper prepared for the conference 'Thinking Ahead on International Trade', Graduate Institute, Geneva (Switzerland), 2010, at p. 6, available at: http://www.wto.org/ english/res_e/reser_e/climate_jun10_e/background_paper5_e.pdf.

9 This difference has been estimated to be in the region of billions of dollars per year in the EU or the United States (US): see P. Wooders, A. Cosbey \& J. Stephenson, 'Border Carbon Adjustment and Free Allowances: Responding to Competitiveness and Leakage', Organisation for Economic Co-operation and Development, Round Table on Sustainable Development, Paris, 23 July 2009, p. 6, available at: http://www.oecd.org/dataoecd/49/17/43975050.pdf. 
through the actual carbon price it creates and through the signal it sends about the need for technology change in order to accomplish a shift to a low-carbon economy.

The idea behind allocating emissions allowances free of charge is that the allowances represent an opportunity cost. This implies that - irrespective of the mode of allocation - the firms covered by the scheme have an incentive to reduce their emissions, as they can then sell the excess allowances for profit. ${ }^{10}$ Nevertheless, there are numerous complexities underlying this relationship. Firstly, opportunity costs and actual outlays are two different things and, typically, firms pay more attention to the latter. Secondly, firms with excess allocation (which is more common when allowances are free) are under little direct pressure to cut emissions at all. ${ }^{11}$ Thirdly, particularly in relation to grandfathering, ${ }^{12}$ there is a risk that if free allocations continue and industries expect future allocations to reflect recent emissions, incentives to reduce emissions in the present will be undermined. Finally, the ability of contributing to reducing emissions seems to be related to the type of cap. Faced with absolute caps, ${ }^{13}$ firms would always factor the effective cost of carbon into their production decisions. For firms with output-based allocation, ${ }^{14}$ the effective cost of carbon they face reduces as a function of the allowances they are rebated. The effective carbon cost could be near zero and firms would have little incentive to reduce emissions. ${ }^{15}$

\subsection{Are Free Allowances Effective in Reducing Competitiveness and Leakage Impacts?}

One of the reasons for granting emissions allowances free of charge is to reduce the risks of distortion in competitiveness and carbon leakage. The starting point is that, irrespective of permit allocation rules, firms pass on much of the carbon cost whenever possible. This is likely to occur even in competitive markets. ${ }^{16}$ If the allowance has been received free of charge, passing on the carbon cost to consumers allows firms to make a profit. ${ }^{17}$ Where this occurs, the justification for competitiveness or leakage claims is substantially weakened.

10 A survey of stakeholders carried out in the EU in 2005 indicated that many participants indeed incorporated the value of allowances in making long-term decisions, particularly in the electric utility sector: European Commission, Directorate General for Environment, 'Review of EU Emissions Trading Scheme: Survey Highlights', Nov. 2005, pp. 5-7.

11 Data suggest that in the aggregate they have not done so: R.N. Cooper, 'Europe's Emissions Trading System', The Harvard Project on International Climate Agreements, Discussion Paper, Aug. 2010, p. 9 , available at http://belfercenter.ksg.harvard.edu/files/CooperETSfinal.pdf.

12 Grandfathering refers to the allocation based on past levels of emissions.

13 Absolute targets for emissions reductions, expressed in terms of emissions.

14 Intensity targets expressed in terms of emissions per unit of output.

15 See Wooders, Cosbey \& Stephenson, n. 9 above, at p. 50.

16 R. Smale, M. Hartley, C. Hepburn, J. Ward \& M. Grubb, 'The Impact of $\mathrm{CO}_{2}$ Emissions Trading on Firm Profits and Market Prices' (2006) 6 Climate Policy, pp. 29-46.

17 Organisation for Economic Co-operation and Development (OECD), The Economics of Climate Change Mitigation: Policies and Options for Global Action Beyond 2012 (OECD, 2009), at p. 88. 
Assuming a carbon leakage risk exists, Wooders, Cosbey and Stephenson claim that:

there is little empirical evidence to suggest whether or not free allowances would be effective. Economic theory strongly suggests that they will have little or no impact in the short term. In the longer term, little is known about how effective free allowances would be in encouraging producers to remain in countries with climate change policies and measures. There must be a strong suspicion that free allowances, which have the nature of a compensatory payment, will have little impact on competitiveness and leakage. ${ }^{18}$

Under both intensity-based and output-based caps, rebates of allowances reduce the effective cost of carbon below the allowance price in the market. This will intuitively reduce leakage and competitiveness risks but, importantly, will also reduce the environmental effectiveness of the policy. A low carbon cost reduces the incentive to abate emissions, thereby leaving the competitive position relatively unaltered.

Thus, the ability of free allocation to reduce the risk for leakage is linked to its ability to actually create incentives to reduce emissions: if the design is such that there is little incentive to abate emissions, then the risk of leakage is intuitively negligible, and the free allocation would not make any significant difference in any direction. If, however, there is an impact on emissions, and thus a risk of leakage, it seems from the above that it remains unclear whether free allocation would contribute to mitigate that risk.

\subsection{Conclusions on the Effectiveness of Free Allowances}

Although countries introducing ETSs are likely to use free allocation of allowances, at least in the initial stages of implementation, it emerges from a preliminary economic analysis that the effectiveness of free allowances in contributing to reducing emissions, while reducing the risks for carbon leakage or competitiveness, is at least questionable.

\section{FREE ALLOWANCES AS SUBSIDY: AN ECONOMIC PERSPECTIVE}

Free trade is an important tool to promote economic growth. In an enabling environment, it can be a cornerstone in the quest for sustainable development. An analysis of climate policy measures with possible implications for trade should be seen as follows: do they support or impede the opportunities for trade to contribute positively to sustainable development? It is in this context that the question of whether free allowances may subsidize domestic production, and thereby potentially distort trade with firms in other countries, becomes important.

\subsection{What is a Subsidy?}

However valuable subsidies may be in supporting various policy goals, they are controversial from a trade perspective as they can interfere with market pricing and resource allocation decisions, as well as distort comparative advantages.

18 Wooders, Cosbey \& Stephenson, n. 9 above, at p. 51. 
From an economic viewpoint, there is no universally accepted definition of a subsidy. ${ }^{19}$ A subsidy could be the 'result of a government action that confers an advantage on consumers or producers, in order to supplement their income or lower their costs'. ${ }^{20}$ This broad definition would also cover market price support in the form of border protection and government infrastructure provided for specific industries at less than full cost.

This broad economic definition is not necessarily identical to any legal definition of a subsidy. A subsidy in economic terms may not be such from a legal standpoint, and vice versa. This is one of the key points that will emerge from the following analysis.

\subsection{Free Allocation as a Potential Subsidy: Six Factors}

The following six factors foster the treatment of freely allocated emissions allowances as potential subsidies.

\section{Financial wealth}

Intuitively, a firm that receives free allowances will be in a stronger financial position than one that has to pay for them. Although free allowances do not (initially) affect a firm's revenues, they reduce the total costs compared with those of firms that must purchase allowances or compared with installations that do not enjoy free allocation. ${ }^{21}$

\section{Over-allocation}

Over-allocation means that a firm is allocated more allowances than it needs to cover its emissions. Excess allowances may be sold for profit, creating an obvious incentive for firms to overstate their needs, thereby avoiding abatement efforts and investments. The problem is particularly relevant when the allocation is based on grandfathering. Indeed, both theory and evidence indicate an upwards bias in projection-based allocations. It is a classic case of information asymmetry: firms simply know more about their production, emissions and investment intentions than do regulators. ${ }^{22}$

19 OECD, Environmentally Harmful Subsidies: Challenges for Reform (OECD, 2005), at p. 7.

20 Ibid, p. 16.

21 M. Åhman, D. Burtraw, J. Kruger \& L. Zetterberg, 'The Ten Year Rule: Allocation of Emission Allowances in the EU ETS', Resources for the Future, Discussion Paper 05-30, June 2005, p. 5, available at: http://www.rff.org/rff/documents/rff-dp-05-30.pdf.

22 See M. Grubb \& K. Neuhoff, 'Allocation and Competitiveness in the EU Emissions Trading Scheme: Policy Overview', Cambridge Working Papers in Economics, No. 0645, June 2006, available at: http://www.eprg.group.cam.ac.uk/wp-content/uploads/2008/11/eprg0622.pdf; and J. Stephenson \& S. Upton, 'Competitiveness, Leakage and Border Adjustment: Climate Policy Distractions?', OECD, Round Table on Sustainable Development, 22-23 July 2009, available at: http://www.oecd.org/dataoecd/ 23/20/43441650.pdf. 
When allocation is based on benchmarking ${ }^{23}$ or on actual output, allowances relate more directly to real needs and performance.

\section{Over-compensation}

Over-compensation occurs when costs are passed on while firms are being compensated for the carbon costs through free allowances, resulting in 'windfall profits'. Of the subsidy elements discussed, the prevalence of windfall profits is the easiest to assess, as the EU ETS case shows. ${ }^{24}$ Both over-allocation and over-compensation can be considered to constitute a net subsidy. ${ }^{25}$ In both cases, firms are compensated for costs they do not in reality incur, without any requirement to actually abate emissions.

\section{Investment subsidy for new entrants}

Setting aside allowances for new entrants is attractive to policy-makers for reasons of equity (treating new entrants and existing plants in the same way) and as a mechanism to attract new investment. At the same time, free allocation to new entrants can be considered an investment subsidy. ${ }^{26}$

\section{Plant closure and production subsidy}

Following the logic of a market-based policy instrument, which favours the most efficient firms and installations and stimulates the least expensive abatement options, an installation should retain its allocation even where it reduces economic activity or closes. ${ }^{27}$ An installation with relatively inferior environmental performance will face relatively greater costs associated with the use of emissions allowances and should therefore give way to installations with higher environmental performance. An operator will close an

23 Benchmarking methodology is designed to avoid the negative effects associated with grandfathering. The principle behind benchmarking is to assess each entity's emissions efficiency against a sector average using a mathematical formula. Allowances are then distributed based on a benchmark of the most efficient installations, to create incentives to reduce emissions.

24 A synthesis of much of the empirical evidence on windfall profits from the EU ETS concludes that total rents have been substantial, even when the carbon price has been modest. All technologies and all participants included in the EU ETS have benefited from ETS-related rents. See C. Egenhofer, M. Alessi, A. Georgiev \& N. Fujiwara, 'The EU Emissions Trading System and Climate Policy Towards 2050: Real Incentives to Reduce Emissions and Drive Innovation?', CEPS Special Report, 2011, pp. 14-6, available at: http://www.ceps.eu/ceps/download/4097. For a helpful discussion of windfalls in the power sector and in the cement industry, see J. Sijm, K. Neuhoff $\&$ Y. Chen, ' $\mathrm{CO}_{2}$ Cost Pass Through and Windfall Profits in the Power Sector', CWPE 0639 and EPRG 0617, May 2006, available at: http://www.eprg. group.cam.ac.uk/wp-content/uploads/2008/11/eprg0617.pdf; F. Gulli (ed.), Markets for Carbon and Power Pricing in Europe: Theoretical Issues and Empirical Analyses (Edward Elgar, 2009); N. Walker, 'Concrete Evidence? An Empirical Approach to Quantify the Impact of EU Emissions Trading on Cement Industry Competitiveness', University College Dublin, Planning and Environmental Policy Research Series, Working Paper 2006/10, available at: http:/www.ucd.ie/gpep/publications/ archivedworkingpapers/2006/06-10.pdf.

25 See Stephenson \& Upton, n. 22 above, at p. 14.

26 M. Grubb 'The European Emissions Trading Scheme: An Overview of Operation and Lessons' (2007) 8(4) CESifo Forum, p. 22, available at: http://www.cesifo-group.de/portal/pls/portal/docs/1/1193136.PDF. In addition, giving free allowances in proportion to the carbon intensity of new plants can bias the incentives towards more carbon-intensive investments, something that would not be beneficial to the aim of reducing emissions. Benchmarking new entrant reserves on the basis of capacity could avoid the worst of distortions.

27 See Åhman, Burtraw, Kruger \& Zetterberg, n. 21 above, at p. 12. 
installation and sell the allowances to a more efficient plant if it is profitable to do so, thus pursuing the efficient solution and fulfilling the intended effect of the scheme.

Withholding the free allowance in the case of closure would turn the allocation into a subsidy to production, as the firm would have the incentive to keep the installation open since it earns the allocation if, and only if, it continues to operate.

\section{Sector bias}

In Phase II of the EU ETS, the allocation of free allowances was biased in favour of the manufacturing sector at the expense of power-generating sectors. The rationale was that the power sector could more easily pass on its increased costs to consumers than could manufacturing firms subject to international competition. Although this may be justifiable from an economic perspective, this practice was not uniform across countries and was therefore capable of creating competitive distortions within the EU. ${ }^{28}$

\subsection{The Impact of Free Allowances on Trade}

It is difficult to draw general conclusions on the potential impact of free allowances on trade. Firstly, one rationale behind free allocation is to prevent carbon leakage, which would occur through variations in trade patterns. Proving the negative is not easy. Secondly, since ETSs and free allowances are relatively recent policy tools, it is still too early to evaluate their effects. Thirdly, and crucially, in order to assess the effects on trade, it would also be necessary to establish the counterfactual for comparison, which is always challenging.

The various subsidy factors outlined above may have different effects on trade. In general terms, the first three (increased financial wealth, over-allocation, and overcompensation), transfer financial resources to heavily polluting industries. This could result in lower product prices, thereby rendering these industries more price competitive on the international market. However, as firms are inclined to pass costs on, the development observed has rather been the opposite, showing increased prices combined with the increased wealth of companies.

Greater wealth may render the recipient firms better placed to invest in research and development, marketing, energy efficiency, new plants or any other priority that might increase their market share in the country where they face a carbon cost. ${ }^{29} \mathrm{~A}$ stronger financial position would also tend to result in secondary benefits, such as lower costs of capital. ${ }^{30}$ All this may, in the long term, lead to a stronger competitive

28 The described problem is in any case likely to be reduced in Phase III of the EU ETS when there will be increased harmonization in the allocation of emission allowances, mainly following the abandonment of the National Allocation Plans (NAPs) since the allocation will be decided at the EU level. On the progressive increased harmonization of the EU ETS, see A. Denny Ellerman, 'The EU Emission Trading Scheme: A Prototype Global System?', The Harvard Project on International Climate Agreements, Discussion Paper, Aug. 2008, available at http://belfercenter.ksg.harvard.edu/publication/18488/ eu_emission_trading_scheme.html.

29 Stephenson \& Upton, n. 22 above, at p. 14.

30 See Wooders, Cosbey \& Stephenson, n. 9 above, at p. 27. 
position, even at the international level, which, in turn, could boost domestic production, displace imports and adversely affect other countries. However, demonstrating that imports are being displaced, and linking such effects to free allocation, is difficult and will need to be judged on a case-by-case basis. ${ }^{31}$

The investment subsidy discussed in relation to new entrants could potentially contribute to influencing investment decisions, thereby having an impact on trade patterns. Additionally, the potential bias between countries, where firms active within the same sectors are treated differently among countries, could possibly affect trade patterns as it would be capable of distorting competition. ${ }^{32}$ The factor relating to plant closure would risk supporting environmentally and economically inefficient plants through a production subsidy.

\subsection{Conclusions on Free Allowances as Subsidies: Economic Perspective}

The foregoing analysis reveals that free allowances involve various factors that, under the broad economic definition of subsidy, would warrant their classification as a subsidy. Further empirical analysis is needed to assess whether the risks attached to the subsidy features identified above have indeed occurred and whether and to what extent they have induced distortions to international trade.

\section{FREE ALLOWANCES AS SUBSIDY: A LEGAL PERSPECTIVE}

It has already been noted that any assessment on whether the free allocation of allowances constitutes a subsidy reached through economic analysis cannot be transposed directly to the legal context. The legal definition of subsidy in WTO law is a precise one. The existence of a subsidy depends not (only) on the economic effects of the conduct of the government but, most importantly, on the positive proof of certain legal requirements. ${ }^{33}$ It is therefore important to determine whether and which of the potential subsidy elements identified in the economic analysis above would fall foul of WTO rules and which type of impact on trade must be proved. In general, the economic concept of subsidy is broader than the legal one, with the crucial consequence that many more activities are likely to be objected to from an economic, as opposed to a legal, perspective. As the following analysis shows, however, there are exceptional cases where economic analysis would conclude that we cannot really talk of a subsidy, with the legal definition being stricter.

31 See Stephenson \& Upton, n. 22 above, at p. 15.

32 For example, in the EU ETS, there is a lack of harmonization with respect to the allocation of allowances to new entrants. Research shows that the annual free allocations to a new natural gas combined-cycle plant would vary from zero allowances in Sweden to as much as allowances worth $€ 11$ million in Germany, at a carbon price of $€ 10$ per ton. See M. Åhman \& K. Holmgren, 'New Entrant Allocation in the Nordic Energy Sectors: Incentives and Options in the EU ETS', IVL Swedish Environment Research Institute, Jan. 2007, p. 8, available at: http://www.ivl.se/webdav/files/B-rapporter/B1710.pdf.

33 The said precision refers to the fact that there are very identifiable requirements, not to the conceptual or practical clarity of those requirements. On the various issues raised by the definition of a subsidy in both the WTO and EU, see L. Rubini, The Definition of Subsidy and State Aid: WTO Law and EC Law in Comparative Perspective (Oxford University Press, 2009). 
It is in the light of the clarification of the difference between economic and legal interpretations of subsidy that one must assess Stiglitz's claim that the failure to ratify the Kyoto Protocol ${ }^{34}$ amounts to a 'negative' subsidy. ${ }^{35}$ In reaching this conclusion, he notes that ' $[\mathrm{a}]$ subsidy means that a firm does not pay the full costs of production. Not paying the cost of damage to the environment is a subsidy, just as not paying the full costs of workers would be'.

Stiglitz's economic language has to be translated into a legal claim and applied within a determined legal framework, in the instant case that of WTO law.

Article 1 of the WTO Agreement on Subsidies and Countervailing Measures $(\mathrm{SCM})^{36}$ provides that a subsidy shall be deemed to exist if there is (i) a 'financial contribution' by the government, ${ }^{37}$ which corresponds with one of the specific forms of action indicated therein, or 'any form of income or price support'; and (ii) this results in a 'benefit'. To be actionable in the WTO dispute settlement system, or to be subject to countervailing duties unilaterally imposed by aggrieved countries, a subsidy also needs to be 'specific' to certain enterprises or industries ${ }^{38}$ and produce 'adverse effects' ${ }^{39}$ or material injury. ${ }^{40}$

We now examine each of these steps, commencing with the definition of a subsidy.

\subsection{Financial Contribution}

A financial contribution under Article 1.1(a)(1) of the SCM exists if one of the following is present: a 'transfer of funds' (item (i)); 'governmental revenue that is otherwise due is foregone or not collected' (item (ii)); or 'a provision of goods or services' (item (iii)). ${ }^{41}$ While the free allocation of allowances does not easily fit within the category of a 'transfer of funds', which refers to specific forms of financial support (such as loans, capital injections and guarantees), it could qualify as either governmental revenue that is foregone, or provision of goods or services. ${ }^{42}$

34 Kyoto Protocol to the United Nations Framework Convention on Climate Change, Kyoto (Japan), 10 Dec. 1997, in force 16 Feb. 2005, available at: http://unfccc.int/kyoto_protocol/items/2830.php.

35 J. Stiglitz, 'A New Agenda for Global Warming' (2006) 3(7) The Economists' Voice, available at: http://works.bepress.com/joseph_stiglitz/1.

36 Marrakesh (Morocco), 15 Apr. 1994, in force 1 Jan. 1995, available at: http://www.wto.org/english/ docs_e/legal_e/24-scm_01_e.htm.

37 Which should be broadly interpreted to cover any 'public body', such as a regulatory authority. See Appellate Body Report, United States - Definitive Anti-Dumping and Countervailing Duties on Certain Products from China (US - AD/CVD), WT/DS379/AB/R, adopted on 25 Mar. 2011 paras. 282-322.

38 Arts. 1.2 and 2 SCM.

39 Arts. 5 and 6 SCM identify three types of adverse effect: injury, serious prejudice and nullification, and impairment of benefits.

40 Art. 15 SCM. Unless subject to countervailing duty investigation, 'specificity' and a negative impact are assumed for export subsidies.

41 Item (iv), which covers those cases where the government provides a financial contribution indirectly, mainly through a private body, is not relevant here, since the government normally allocates allowances itself.

42 See L. Henschke, 'Going it Alone on Climate Change: A New Challenge to WTO Subsidies Disciplines Are Subsidies in Support of Emissions Reductions Schemes Permissible under the WTO' (2012) 11(1) World Trade Review, pp. 27-52, at 30-9. 


\section{Government revenue that is otherwise due is foregone}

By not charging for the allocation of emissions allowances, the government is foregoing revenue for the use of a natural resource that it controls. It is, however, insufficient to rely on the consideration that the government could in principle have charged for the use of its resources but has not done so. The crucial issue is whether this revenue would have otherwise been due. This requires a precise point of reference, the identification of a benchmark. As evidenced by the US - Foreign Sales Corporation (US - FSC) litigation, ${ }^{43}$ the 'otherwise due' language is ambiguous and requires a complex counterfactual analysis that ultimately rests on a determination of whether the measure under examination is a derogation from the norm. ${ }^{44}$

Relying on the case law on tax matters (US-FSC), Bhagwati and Mavroidis reaffirm the prerogative of WTO Members to define their own environmental policy, for example, by deciding whether or not to join the Kyoto Protocol. ${ }^{45}$ Subsidy laws, as such, do not aim to harmonize environmental policies at the global level by forcing Members to accept the standards adopted by other countries or requiring them to enter into an international treaty. For the same reason, it does not seem appropriate to assess the omission of one government against what other governments do. In the absence of binding and precise obligations, the simple omission to adopt certain environmental standards is not in itself a subsidy.

The presence of an international standard only becomes relevant under subsidy laws if it gives rise to a clear prescriptive norm, one which should be followed as a matter of law. This norm would be the otherwise due benchmark in our case. If this baseline required a payment for the allocation of emissions permits, the decision of a government to allocate allowances free of charge would involve foregoing government revenue otherwise due.

There is no international norm that expressly requires such a payment. Neither the United Nations Framework Convention on Climate Change (UNFCCC) ${ }^{46}$ nor any other international agreement provides an obligation to introduce an ETS. Consequently, they do not indicate whether, where such a scheme exists, allowances should be auctioned or otherwise sold.

An interesting question is whether one could invoke the polluter pays principle (PPP), as a general principle of environmental law, at both the international and domestic levels. ${ }^{47}$ If the prevailing norm is that those that pollute should be liable, to

43 US - Tax Treatment for 'Foreign Sales Corporations', DS108.

44 See Rubini, n. 33 above, at pp. 263-74. For a recent discussion on the 'otherwise due' test, see Appellate Body Report, United States - Measures Affecting Trade in Large Civil Aircraft (Second Complaint) (US - Aircraft), WT/DS353/AB/R, adopted on 23 Mar. 2012, paras. 816 et seq.

45 J. Bhagwati \& P.C. Mavroidis, 'Is Action Against US Exports for Failure to Sign Kyoto Protocol WTO-Legal?' (2007) 6(2) World Trade Review, pp. 299-310, at 302-3.

46 New York, NY (US), 9 May 1992, in force 21 Mar. 1994, available at: http://unfccc.int.

47 This approach is followed in EU state aid law. See the Opinion of Advocate General Jacobs in Case C-126/01, Ministre de l'Économie, des Finances et de l'Industrie v. GEMO SA [2003] ECR I-13769, paras. 66-71. On the PPP generally, see P. Schwartz, 'Polluter Pays Principle', in F. Malgosia and D. Ong (eds.), Research Handbook on International Environmental Law (Edward Elgar, 2010), pp. 243-61. 
relieve a firm from paying for its emissions would clearly run counter to this principle. Using Stiglitz's language, emissions costs, being costs occasioned by the process of production, should normally be borne by firms. This is what the PPP requires.

Assuming one can derive a normative benchmark from the PPP, its precise impact would depend on the absence of other devices to internalize the costs of GHG pollution. Accordingly, the PPP would be breached only if the free allocation of allowances results in an overall and substantial relief from emissions costs. If the social costs of GHG pollution are internalized by other means, such as regulation or taxation, the fact that emissions allowances are granted free of charge does not necessarily involve a lessening of environmental liability.

Alternatively, if the benchmark cannot be derived from a general principle such as the PPP, it should be found in the specific legal framework of the ETS. Thus, the general norm in domestic law with respect to allowances allocation is what needs to be identified. Presently, existing ETSs allocate virtually all allowances for free. However, the fact that at least some allowances are auctioned could possibly confirm the existence of an 'otherwise due' scenario and offer a possible baseline. Further, the regulatory framework may provide that, at a certain point in time in the future, a larger share of allowances will be auctioned or otherwise distributed with a charge. ${ }^{48}$ An interesting legal question is thus whether this progressive phasing out of free allocations can help to establish that the current scenario of free allocations is exceptional and the charge, or price, would be otherwise due. This is not an easy route, as the natural reading of 'government revenue otherwise due is foregone' seems to refer to what is presently due.

One final issue concerns a measure's classification as tax revenue. Item (ii) of Article 1.1(a)(1) of the SCM seems to refer mainly to tax measures. ${ }^{49} \mathrm{In}$ fact, the usual reading links item (ii) exclusively with tax measures. ${ }^{50}$ This would mean that a positive conclusion in this case would depend on the possibility of considering the charge for allowances as a tax. However, the language of the law is sufficiently broad that one could alternatively argue that any instance where government (hence, not necessarily fiscal) revenue is foregone is covered by item (ii). If this argument becomes acceptable, and the 'otherwise due' benchmark has been identified and strayed from, the free allocation of allowances would constitute a financial contribution.

\section{Provision of goods or services}

In case one finds that the allocation of emissions allowances free of charge does not qualify as a financial contribution as defined in item (ii), the same Article 1.1(a)(1) of the SCM offers one possible alternative. Item (iii) lays down another form of financial

48 The EU ETS should be fully based on auctioning by 2027.

49 The example provided is 'fiscal incentives such as tax credits'.

50 The recent finding of the Appellate Body in US - Aircraft, n. 44 above, para. 615, which interpreted item (i) so that 'the inclusion of specific examples [...] provides an indication of the types of transactions intended to be covered by the more general reference', seems to support the limitation of item (ii) to fiscal measures. 
contribution, where the government "provides goods or services'.51 Although the precise characterization of emissions allowances as goods or services does not change the final conclusion, as the SCM applies to both cases, it is interesting to analyze this classification issue in more detail. ${ }^{52}$

Allowances could be considered as goods. They have economic value, not only because they can be allocated for consideration (that is, financial reward or another form of economic return), but especially because, if they are not needed to satisfy the individual cap, they can be traded on the market as securities. Moreover, inasmuch as securities can be regarded as financial instruments, their transfer can be held to involve financial services. ${ }^{53}$

It could even be asked whether the permission to exploit the atmosphere, which is in essence what emissions allowances bestow, amounts to the provision of a good, a natural resource that can be used and subjected to economic transactions. ${ }^{54} \mathrm{An}$ analogy could here be drawn with the US - Lumber IV dispute, ${ }^{55}$ in which the Appellate Body faced the question of whether the permit to harvest lumber on Crown land of certain Canadian Provinces amounted to a provision of goods under Article 1.1(a)(1)(iii). The counter-argument presented by Canada was that the right to reap a natural resource could not be equated to the actual, direct provision of the same resource. The Appellate Body, however, upheld the Panel's finding that the grant of a right to harvest lumber amounts to the provision of a good. ${ }^{56}$ Reasoning otherwise would have meant an unduly restrictive construction of the term 'provide', which is open-ended. This finding is particularly instructive for the present analysis. The free allocation of emissions allowances is essentially the grant of an entitlement to pollute a natural resource, namely the atmosphere, which is similar to the grant of a right to harvest lumber. From this perspective, too, one can suggest that the allocation of emissions allowances should qualify as a provision of goods under item (iii).

Sound arguments exist, therefore, to conclude that the emissions allowances do involve the provision of goods and/or services and thereby constitute a form of financial contribution under Article 1 of the SCM.

51 The two options are not mutually exclusive; depending on the perspective, an emissions allowance could constitute a good and a service: see Appellate Body Report, European Communities - Regime for the Importation, Sale and Distribution of Bananas (EC - Bananas), WT/DS16/AB/R, para. 221.

52 See E. Vranes, 'Climate Change and the WTO: EU Emission Trading and the WTO Disciplines on Trade in Goods, Services and Investment Protection' (2009) 43(4) Journal of World Trade, pp. 707-35.

53 Which may engage the WTO's General Agreement on Trade in Services (GATS), Marrakesh (Morocco), 15 Apr. 1994, in force 1 Jan. 1995, available at: http://www.wto.org/english/docs_el legal_e/26-gats_01_e.htm.

54 R. Howse, 'Climate Change Mitigation Subsidies and the WTO Legal Framework: A Policy Analysis', International Institute for Sustainable Development, May 2010, pp. 12-13, available at: http://www.iisd. org/pdf/2009/bali_2_copenhagen_subsidies_legal.pdf.

55 Appellate Body Report, United States - Final Countervailing Duty Determinations with respect to Certain Softwood Lumber from Canada (US - Softwood Lumber IV), WT/DS257/AB/R, adopted on 17 Feb. 2004.

56 Ibid., paras. 57-76. If the benefit analysis of the Appellate Body (see paras. 82-122) is controversial because contra legem this is not the case for the financial contribution analysis outlined in the text. 


\subsection{Income Support}

According to Article 1.1(a) of the SCM, a subsidy is deemed to exist if there is a financial contribution or, alternatively, 'any income or price support in the sense of Article XVI of GATT $1994^{57}$ - that is, support 'which operates directly or indirectly to increase exports of any product from, or to reduce imports of any product into' the territory of the subsidizing country.

This limb of the definition of a subsidy is relatively unexplored. ${ }^{58}$ It has been suggested that it should be limited to support in the agricultural sector ${ }^{59}$ However, because of its broad and open-ended language, this provision has huge potential for more extensive application and is increasingly referred to, for example, in the context of policy measures to fight climate change, such as feed-in tariffs. ${ }^{60}$

Following this line of thought, it could be argued that the free allocation of allowances is a form of income support, particularly in the form of an increase in wealth, which may produce an impact on trade. ${ }^{61}$

\subsection{Benefit}

To qualify as a subsidy under the SCM, a financial contribution or a measure of income support has to confer a benefit. This requires establishing that the recipient is 'better off' than it would have been absent the alleged subsidy. ${ }^{62}$ Even if the essence of the benefit conferred by free allowances is undisputed, as is the fact that the recipient

57 General Agreement on Tariffs and Trade (GATT 1994), Marrakesh (Morocco), 15 Apr. 1994, in force 1 Jan. 1995, available at: http://www.wto.org/english/docs_e/legal_e/06-gatt_e.htm.

58 The only official interpretation by the WTO can be found in the very recent Panel Report, China Countervailing and Antidumping Duties on Grain Oriented Flat-Rolled Electrical Steel from the United States (China-GOES), decision of 15 June 2012, paras. 783-8.

59 R.W. Staiger \& A.O. Sykes “"Currency Manipulation” and World Trade' (2010) 9(4) World Trade Review, pp. 583-627, at $610 \mathrm{fn}$. 52. On the history of this language and arguing for a broad interpretation, see J. Lambert \& S. Rueffer, Export Taxes under WTO Agreements, Legal Memo to the Mexican delegation, 10 June 2010, available at: http:/www.graduateinstitute.ch.

60 S.Z. Bigdeli, 'Incentive Schemes to Promote Renewables and the WTO Law of Subsidies', in T. Cottier, O. Nartova \& S.Z. Bigdeli, International Trade Regulation and the Mitigation of Climate Change (Cambridge University Press, 2009), pp. 155-92, at 170; Howse, n. 54 above, at p. 14; Rubini, n. 33 above, at pp. 123-5. The recent Canada - Certain Measures Affecting the Renewable Energy Sector (DS 412) and Canada - Measures Relating to the Feed-In Tariff Program (DS 426) disputes, where the local content requirement of a Canadian feed-in-tariff system is challenged, may provide the opportunity to explore the notion of 'income or price support'.

61 It should be noted that this rests on an interpretation of 'income support' which may be warranted after the Panel, China - GOES decision (n. 58 above) which, interpreting the sister concept of 'price support', found that this would involve the government 'setting and maintaining' a fixed level, rather than 'a random change [in price] merely being a side-effect of any form of government measure': ibid., at para. 7.86. As noted in section 3.2 above, a free transfer of allowances necessarily increases the financial wealth of the recipient firm.

62 Appellate Body Report, Canada - Measures Affecting the Export of Civilian Aircraft (Canada Aircraft), WT/DS70/AB/R, adopted on 4 Aug. 2000, para. 157. 
firm does not pay what should be paid (whether a price, a tax or compensation for damage to the environment), ${ }^{63}$ what is far less evident is what benchmarks should be used in actual cases to reach a determination that a benefit has been given and how to calculate it.

If the free allocation of allowances is determined to entail 'government revenue that has been foregone' (item (ii) of Article 1.1(a)(1)), there is almost certainly a benefit, since the recipient firm has spent less than it would have done under normal circumstances. ${ }^{64}$ If, by contrast, the allocation is considered to constitute a provision of goods or services (as under item (iii) of Article 1.1(a)(1)), the question becomes whether the allowances would have been available for free under normal market conditions. ${ }^{65}$ This market determination is a complex task, particularly in the absence of reliable data owing to the still nascent nature of ETSs, and the risks of having to resort to constructed baselines focusing on a hypothetical market operator. ${ }^{66}$ These difficulties would also exacerbate the actual calculation of the benefit which is crucial, for example, for determining the level of countervailing duties.

The economic analysis has revealed various elements of economic advantage in the allocation of allowances free of charge. Do they also constitute a benefit from the legal viewpoint? As noted, the economic and legal interpretations of subsidies do not necessarily coincide. The benefit determination is a good example of this difference, with the legal test limiting the kind of measures that could amount to a subsidy.

In some cases, there is accord between economic and legal analysis. If the improvement of the financial position of the recipient (first element in the economic analysis) results from the fact that the circumstances of the allocation - and notably its gratuity are not in line with normal market conditions, this is a benefit. Similarly, any overallocation or over-compensation (second and third elements) which would not occur in normal market conditions is a benefit. ${ }^{67}$

In contrast, while the extension of free allocation of allowances to new entrants, or its withdrawal from closing plants, may constitute a subsidy from an economic perspective, they are not in themselves subsidies from a legal viewpoint.

63 We leave aside here the more general questions of whether the subsidy is conferring a benefit or is rather compensating for a disadvantage. For an analysis of these questions, see A.O. Sykes, 'The Questionable Case for Subsidies Regulation: A Comparative Perspective' (2010) 2(2) Journal of Legal Analysis, pp. 473-523. See also Jegou \& Rubini, n. 7 above, at pp. 33-4.

64 Rubini, n. 33 above, at p. 263.

65 This marketplace does not seem an absolute benchmark, however. The Appellate Body itself (CanadaAircraft, n. 62 above, para. 157) underlined that the marketplace is just 'an appropriate basis for comparison' [emphasis added], thus opening the door to alternative yardsticks.

66 An interesting issue is whether these normal market conditions should refer to an emissions trading scenario with full auctioning or, more radically, to a situation with no market-based systems, without an ETS in place. It appears 'natural' to consider existing conditions as normal conditions, thus, conditions available under the ETS at issue or similar schemes (in the jurisdiction), including the allocation mode of allowances.

67 Another possible dimension of benefit (albeit an indirect one that may go beyond the current legal framework of analysis) may come from the economic finding that free allocation may undermine the incentives to reduce emissions. In such a case, the advantage derives from the fact that the firms receiving free allowances are not only relieved from the costs of the emissions but also from the costs of the activities and investments necessary to be more efficient in their reduction. 
It is important to remember that the key characteristic of the legal concept of a subsidy is not simply a transfer of economic resources but rather a transfer of economic resources which is also an exception to the norm. Legally, the free allocation of allowances would be a subsidy because its free nature derogates from what would have normally occurred - an otherwise due tax is not collected, an otherwise due compensation is not paid, an otherwise due price is not disbursed. Accordingly, if allowances were given away only to existing plants and auctioned to new entrants, there would still be a subsidy, but one in favour of incumbents that benefit from free allocation. ${ }^{68}$ Similarly, it is not the withdrawal of (free) allowances from closing plants that is objectionable as a production subsidy, but the allocation of allowances free of charge in the first place. Further, while discrepancies in allocation between different countries or regions participating in the ETS (for example, with respect to the position of new entrants) may well distort the market in so far as they affect the investment decisions of firms active within the same sectors, this would not necessarily constitute a subsidy from a legal standpoint. What still must be proved, in the first place, is that the free allocation system operating in a given country derogates from a benchmark principle of auctioning that generally governs the distribution of allowances in that ETS.

One further example illustrates the scope for a possible discrepancy between the economic and legal assessment. The bias in favour of certain sectors may be justified from an economic perspective because it compensates for various circumstances, but it is harder to justify legally. ${ }^{69}$ Whilst a crucial objective of subsidy disciplines is to determine whether the subsidy confers a competitive benefit, the goal of the benefit analysis is more limited. It aims to ascertain whether, by virtue of the governmental action, the recipient of the subsidy finds itself in a more advantageous position than it was in before the subsidy. This begs for a counterfactual analysis that operates by reference to a positive alteration of the status quo. Whether the subsidy only compensates for a disadvantage or cost, or rather affects the competitive position of the recipient and its relation with competitors, is an issue that is analyzed subsequently and separately when the actual effects of the subsidy on trade are determined under the 'adverse effects' test. ${ }^{70}$

\subsection{Specificity}

A subsidy is subject to WTO scrutiny only if it is specific 'to an enterprise or industry or group of enterprises or industries' (Article 2.1 of the SCM). ${ }^{71}$ Specificity is a very

68 The scenario is different if there is a clear point in time which signals the passage from a free-of-charge scenario to a fully auctioning scenario. Old and new production units would thus belong to different regime periods of the ETS with different prevailing benchmarks.

69 See Jegou \& Rubini, n. 7 above, at pp. 33-4, warning against the dangers of charging the benefit analysis with too many considerations which potentially extend to every possible positive or negative occurrence affecting the position of the recipient firm.

70 See also Henschke, n. 42 above, at pp. 39-43. The possibility of considering any disadvantage or cost in the context of the benefit analysis, or indeed its calculation under Art. 14 SCM would, in our view, require a complete redefinition of the law.

71 For a comprehensive exposition of the specificity test, see Appellate Body Report, US - AD/CVD, n. 37 above, paras. 363-78. As mentioned, if a subsidy is found to be a prohibited subsidy, it is automatically deemed to be specific and thus not subject to the specificity test. 
pliable test that also shows a certain degree of expansion. ${ }^{72}$ Article 2.1 of the SCM provides three different principles by which to establish specificity. Specificity is present if the measure explicitly limits access to the subsidy to certain enterprises (de jure specificity, subparagraph (a)). If the eligibility to the subsidy is governed by 'objective criteria or conditions', there is no specificity (subparagraph (b)). However, according to the final subparagraph (c), which introduces the notion of de facto specificity, 'if notwithstanding any appearance of non-specificity resulting from the application of the principles laid down in subparagraphs (a) and (b), there are reasons to believe that the subsidy may in fact be specific, other factors may be considered'. These factors are:

use of a subsidy programme by a limited number of certain enterprises, predominant use by certain enterprises, the granting of disproportionately large amounts of subsidy to certain enterprises, and the manner in which discretion has been exercised by the granting authority in the decision to grant a subsidy [footnote omitted]. In applying this subparagraph, account shall be taken of the extent of diversification of economic activities within the jurisdiction of the granting authority, as well as of the length of time during which the subsidy programme has been in operation. [...]

As recently cautioned by the Appellate Body, the specificity test requires the concurrent application of the principles outlined in subparagraphs (a), (b) and (c) of Article 2.1. ${ }^{73}$ This is particularly true in the case of free allocation of allowances in emissions trading schemes where various considerations can be put forward.

One line of argument could be that the free allocation is not specific because, although the ETS has a narrow coverage, the free allowances are accessible to everyone within the system. However, the mere fact that an ETS applies only to a few 'certain' sectors of the economy might suffice to conclude that the allocation of allowances free of charge, even if applicable to all industries covered by the system, is sufficiently specific. Although specificity is a 'general concept, and the breadth or narrowness of specificity is not susceptible to rigid quantitative definition' but should rather 'modulate according to the particular circumstances of a given case', ${ }^{74}$ it seems that how many sectors of the economy are benefited is not really important if the subsidy is not 'sufficiently broadly available throughout the economy' ${ }^{75}$ It could even be argued that the subsidy granted through free allowances is already in law (or de jure) specific since the laws establishing the emissions trading scheme expressly define their scope of application and, in so doing, 'explicitly limit access to the subsidy' to certain enterprises.

72 See Rubini, n. 33 above, Chapter 13, at pp. 359-77.

73 Appellate Body, US - AD/CVD, n. 37 above, para. 371.

74 Panel Report, United States - Subsidies to Upland Cotton (US - Cotton), WT/DS/267/R, adopted on 21 Mar. 2005, para. 7.1142.

75 Ibid. On the interpretation of 'sufficiently broadly available' (as different from 'universally available') and interpreting selective as 'sufficiently limited', see Panel Report, United States - Measures Affecting Trade in Large Civil Aircraft (Second Complaint) (US - Aircraft), WT/DS353/R, adopted on 23 Mar. 2012, paras. 7.762 and 7.1237. See also the rather open-ended approach to specificity in Panel Report, United States - Final Countervailing Duty Determinations with respect to Certain Softwood Lumber from Canada (US - Softwood Lumber IV), WT/DS257/R, paras. 7.115-7.122. 
Assuming, for the sake of argument, that there is no de jure specificity (perhaps because the ETS would be fairly advanced and almost universal in its application), it could be argued that the legislation is not specific because it 'establishes objective criteria or conditions governing the eligibility for' the free allocation of allowances. This, however, is a difficult battleground. The terms 'objective criteria or conditions' refer to 'criteria or conditions which are neutral, which do not favour certain enterprises over others, and which are economic in nature and horizontal in application, such as number of employees or size of enterprise'. ${ }^{76}$ These represent multiple tests of impartiality and rationality of an ETS design and, most importantly for this analysis, of the free allocation of allowances within it. It remains to be seen whether the energy and carbon emissions intensity - which represents the prevalent common denominator of the industries eligible for the allocation of allowances free of charge - will be considered to be a criterion that is not only neutral and impartial but also 'economic in nature and horizontal in application'.

Complainants may be successful in challenging the free allocation of allowances if they prove that one of the circumstances indicating de facto specificity is present, namely 'use of a subsidy programme by a limited number of certain enterprises, predominant use by certain enterprises, the granting of disproportionately large amounts of subsidy to certain enterprises, and the manner in which discretion has been exercised by the granting authority in the decision to grant a subsidy' ${ }^{77}$ The fact that this 'dominance' test is outlined after the 'objectivity criteria', and should apply whenever the application of the other tests leaves a doubt about the specificity of the measure, seems to give pre-eminence to the former over the latter. ${ }^{78}$ Even in the case of application of the ETS and the free allocation of allowances across the board, it remains unavoidable that, because of the distinct factual pattern of carbon emissions, only certain industries will benefit from the free allocation of allowances. This, at least according to two of the indicators outlined above (predominant use and concentration of large part of the subsidy), points to the presence of specificity.

\subsection{Adverse Effects}

Specific subsidies may be actionable if they cause adverse effects to the interests of other countries. Subsidized imports causing material injury to the domestic industry of the complaining country may also be subject to countervailing duty actions.

It is worth noting that Articles 5 and 6 of the SCM provide various tests of adverse effects: (i) injury to the domestic industry; ${ }^{79}$ (ii) nullification and impairment of benefits, which is essentially the frustration by the subsidy of market access opportunities that other WTO Members could reasonably expect from tariff concessions; and (iii) serious prejudice. Article 6 of the SCM defines serious prejudice in various

76 Footnote 2 SCM.

77 Art. 2.1(c) SCM.

78 Appellate Body, US - Aircraft, n. 44 above, para. 796.

79 The concept of injury applies also in the countervailing duty context. 
ways: (a) displacement or impediment of imports of a like product of another Member into the subsidizing Member's market; (b) displacement or impediment of exports of a like product of another Member from a third country market; (c) significant price undercutting of the subsidized product as compared with the price of a like product of another Member, significant price suppression, depression, or lost sales in the same market; and (d) increase in the world market share of the subsidizing Member in a particular subsidized primary product.

These four tests show that subsidized products may cause harm in different ways. A common pattern is that the financial advantage deriving from the free allocation translates into production decisions, thereby affecting trade mainly in terms of lower prices or larger output and thus harming competitors in one of the identified ways. However, it is clear that, as currently interpreted by the WTO dispute settlement system, the law does not always require that all of these separate steps be proven. Thus, in 'injury' cases, an effect on volumes and prices with a connection with the subsidized imports is generally sufficient. In serious prejudice claims, by contrast, the analysis seems to rely substantially on the competitive impact of the subsidy, ${ }^{80}$ following an analytical approach reminiscent of antitrust assessment. ${ }^{81}$

Clearly, any determination of the adverse impact on trade must be based on the actual scenario and must take into account various elements of the legal standard challenged. A case-by-case analysis is thus required. That being said, drawing upon the economic analysis performed above, we can make a few general observations.

Firstly, free allocation undeniably increases the financial wealth of the recipients. What is not clear, however, is whether this advantage translates into a distortion of international trade. Subsidy laws are not concerned with mere financial benefits but with competitive benefits - that is, advantages that impact upon the competitive conduct of recipient firms; this can thus harm international competition by boosting domestic production at home or abroad and displacing foreign imports or exports. To be considered as subsidies, the other economic consequences of free allowances should also create a competitive benefit. Further, any bias between firms operating in the same sector, and active in international trade, is more likely to lead to adverse effects as compared with a bias between different, and not competing, sectors.

Secondly, the empirical evidence available indicates that firms receiving free allowances tend to pass on costs (rather than keeping prices unchanged) with the result that, at least in the short term, no major trade effects have been detected. Things may be different in the long term if the noted increase in financial wealth eventually translates into a stronger competitive position, even internationally. Any impact on production and trade patterns can, however, only be relevant for subsidy

80 See, e.g., Panel Report, European Communities - Measures Affecting Trade in Large Civil Aircraft (EC-Aircraft), WT/DS316/R; Panel, US - Aircraft, n. 75 above; Appellate Body Report, United States Subsidies to Upland Cotton (US - Cotton), WT/DS 267/AB/R; United States - Subsidies to Upland Cotton (Art. 21.5 DSU) (US - Cotton 21.5), WT/DS267/AB/RW; European Communities - Measures Affecting Trade in Large Civil Aircraft (EC-Aircraft), WT/DS316/AB/R, adopted on 1 June 2011; and US - Aircraft, n. 44 above. On the various adverse effects tests, see Rubini, n. 33 above, Chapter 14, at pp. 381-418.

81 See Appellate Body, EC - Aircraft, ibid., and Appellate Body, US - Aircraft, n. 44 above. 
laws if the pertinent tests (of displacement, impediment, lost sales, increase in market shares, and so on) are satisfied. Any claim must be duly substantiated. What is needed is an empirical investigation on a case-by-case basis.

\subsection{Prohibited Subsidies}

It cannot be excluded that, in certain cases, the allocation of allowances free of charge could constitute a prohibited subsidy. Subsidies contingent on - that is, conditional or dependent on - export performance are prohibited.

The EU ETS offers a good case study. Many sectors on the EU list of carbon leakage sensitive sectors, which are eligible to receive allowances free of charge, have been included purely on the basis of their trade intensity as calculated from two variables: imports and exports. ${ }^{82}$ The legal discussion would focus on whether there is an element of contingency. Export contingency is present when the measure generates the incentive to export in a way that deviates from the normal supply and demand process. ${ }^{83}$ While there is no doubt that free allowances are granted because of the trade activity of the recipient, an obvious argument against finding prohibited subsidy would be that exports are only one of the two alternative variables to determine trade intensity and seem to bear an equal weight to imports. High trade intensity, and thus eligibility to receive free allowances, can be established solely on the basis of high imports. ${ }^{84}$

\subsection{Conclusions on Free Allowances as Subsidies: Legal Perspective}

The analysis has shown that the evaluation of free allowances under WTO subsidy rules does not always match the economic evaluation. If few aspects of economic advantage resulting from the allocation of allowances free of charge may also eventually constitute a subsidy that is objectionable at law, there are important exceptions. On the one hand, some economic advantages are not relevant for the legal analysis. On the other hand, contrary to legal analysis, economic interpretation may lead us to conclude that a measure that simply compensates for a disadvantage is not really a subsidy - for example, when free allocation allegedly addresses competitiveness or leakage concerns. Despite these differences, there is substantial scope to treat free allowances as subsidies that contravene WTO legal disciplines.

The possible finding that the free allocation of allowances constitutes a subsidy and that such a subsidy is, in principle, actionable or countervailable under WTO law

82 This follows the definition of trade intensity adopted in Directive 2003/87/EC Establishing a Scheme for Greenhouse Gas Emission Allowance Trading within the Community and Amending Council Directive 96/61/EC [2003] OJ L275/32, Art. 10a(16): 'A sector or subsector is also deemed to be exposed to a significant risk of carbon leakage if ... (b) the intensity of trade with third countries, defined as the ratio between the total value of exports to third countries plus the value of imports from third countries and the total market size from the Community (annual turnover plus total imports from third countries), is above $30 \%$.'

83 Appellate Body, EC - Aircraft, n. 80 above, para. 1036 et seq.

84 See Panel, US - Aircraft, n. 75 above, para. 7.1542, which rejected the EC argument that a subsidy contingent on sales, whether domestic or export sales, does amount to an export subsidy. 
is not, however, the final step of the legal analysis. It is important to examine whether an otherwise objectionable subsidy is justified on the basis of its policy objectives. In the absence of specific subsidy provisions offering a legal shelter (a limited category of exceptions, also for environmental goals, expired in 1999), ${ }^{85}$ the inquiry shifts to the question of whether possible grounds for justification exist in the broader WTO legal system, that is, in other WTO-covered agreements. The natural candidate is Article XX of the General Agreement on Tariffs and Trade (GATT). ${ }^{86}$

\section{THE LEGAL JUSTIFICATION FOR FREE ALLOWANCES: ARTICLE XX OF THE GATT AND BEYOND}

The GATT regulates trade in goods. It includes basic disciplines on subsidies (Articles VI and XVI) and a significant set of exceptions. Article XX of the GATT provides the 'general exceptions' and has a special relevance for environmental measures.

Article XX of the GATT is a crucial provision for the functioning of the GATT with a distinct normative value. ${ }^{87}$ Since its inception in 1947, Article XX has contained the express recognition of non-trade based values, prominently including the environment, and the possibility for these values to trump trade under certain circumstances. Indeed, '[t]hese exceptions clearly allow Members, under specific conditions, to give priority to certain societal values and interests over trade liberalization'. ${ }^{88}$ It is for this special role that Article XX has consistently and increasingly been interpreted broadly. ${ }^{89}$

\subsection{The Applicability of Article XX to the SCM Agreement}

Before considering whether free allowances could pass muster of the substantive requirements of GATT Article XX, it is necessary to answer the preliminary question of whether Article XX can in fact apply beyond the GATT and, in particular, whether it is applicable to subsidies regulated by the SCM.

The detailed analysis of this question is beyond the scope of this article. ${ }^{90}$ The question, which is gaining in prominence in academic debate and in litigation, remains unsettled. What, however, can be agreed on is that (i) the current state of the case law does not allow excluding the possibility that the GATT can be applied outside the confines of the agreement itself, and (ii) if it can be extended to other agreements, the

85 Arts. 8 and 9 SCM.

86 See n. 57 above.

87 J. Pauwelyn, 'US Federal Climate Policy and Competitiveness Concerns: The Limits and Options of International Trade', Nicholas Institute Working Paper NI-WP 2007/02, Duke University, defined the chapeau as 'the most important provision in the entire GATT agreement', available at: http://nicholasinstitute. duke.edu/climate/policydesign/u.s.-federal-climate-policy-and-competitiveness-concerns-the-limits-andoptions-of-international-trade-law.

88 P. Van den Bossche, The Law and Policy of the World Trade Organization: Text, Cases and Materials (Cambridge University Press, 2008), at p. 616.

89 Ibid, at p. 618.

90 See L. Rubini, ‘Ain't Wastin' Time No More: Subsidies for Renewable Energy, the SCM Agreement, Policy Space and Law Reform’ (2012) 15(2) Journal of International Economic Law, pp. 525-79, at 558-67. 
SCM is a plausible candidate. Hence, the question of whether free allowances-assubsidies could be justified under Article XX of the GATT is relevant.

In the following analysis, we assume that Article XX can apply to subsidies.

\subsection{Article XX and Free Allowances}

Assuming that Article XX of the GATT can apply to the SCM, it is necessary to determine whether free allowances could satisfy the various substantive requirements of this provision.

In the US - Gasoline case, the Appellate Body presented the two-tiered approach that should be used under Article XX of the GATT. ${ }^{91}$ According to this test, firstly, the existence of a provisional justification of the measure at issue will have to be determined under one of the subparagraphs of Article XX, which includes two 'exceptions' with environmental relevance: paragraphs (b) and (g). Paragraph (b) concerns measures that are 'necessary to protect human, animal or plant life or health', thus covering not only public health policy measures but also 'environmental' ones. Paragraph $(\mathrm{g})$, on the other hand, refers to 'measures relating to the conservation of exhaustible natural resources'. 92

Secondly, if the existence of a provisional justification is established, it must then be determined whether the measure is applied in conformity with the chapeau, which reads as follows:

Subject to the requirement that such measures are not applied in a manner which would constitute a means of arbitrary or unjustifiable discrimination between countries where the same conditions prevail, or a disguised restriction on international trade, nothing in this Agreement shall be construed to prevent the adoption or enforcement by any contracting party of measures.

While the analysis of the exception focuses on the measure itself, under the chapeau it is the application of the measure that is under scrutiny.

In its early case law, the Appellate Body showed that Article XX is about balancing the 'general rule' that is breached and the 'exception' that is invoked as a defence. ${ }^{93}$ There truly is a 'weighing and balancing exercise' of different values that are central to the operation of this provision in each of its steps. ${ }^{94}$ This is the typical hermeneutic process of general clauses where the protection of different values has to be assessed on a case-by-case basis. ${ }^{95}$

\footnotetext{
91 Appellate Body, United States - Standards for Reformulated and Conventional Gasoline (US - Gasoline), WT/DS2/AB/R, adopted on 20 May 1996, p. 20.

92 Although partly overlapping, the focus of the two exceptions differs slightly.

93 Appellate Body, US - Gasoline, n. 91 above, at pp. 16-7.

94 P. Eeckhout, 'The Scales of Trade: Reflections on the Growth and Functions of the WTO Adjudicative Branch' (2010) 13(1) Journal of International Economic Law, pp. 3-26.

95 This process does not necessarily require a precise cost-benefit analysis, but what is, in substance, a proportionality assessment. An informative taxonomy of 'trade-off' adjudicative 'devices' can be found in J.P. Trachtmann, The Economic Structure of International Law (Harvard University Press, 2008), at pp. 222-3.
} 


\section{Environmental justifications}

Several objectives are put forward in justification of the practice of free allocation of allowances: defensive goals (competitiveness and carbon leakage concerns), proactive objectives (supporting efforts to reduce GHGs) and political purposes (increasing the acceptability of the costs of emissions reduction efforts and attempts to ease the industry's adjustment process to participation in ETSs).

If we apply Article XX of the GATT to the premise that the allocation of allowances free of charge is an actionable or even prohibited subsidy, there are two possible lines of defence that both revolve around the alleged environmental merits of free allocation. ${ }^{96}$ The first argument would rely on the contribution of free allocation to the reduction of GHG emissions. However, the previous economic analysis shows that, at best, free allowances are as efficient as paid allowances when regarded as opportunity costs. At worst, they may diminish the incentives to reduce emissions, thus going squarely against the proposed aim of emissions trading schemes. The second argument would rely on the prevention of carbon leakage as a justification. This seems to be the most logical line of defence and will therefore be analyzed for its merits below. ${ }^{97}$

The Appellate Body has already found in Brazil-Retreated Tyres that paragraph (b) on, inter alia, public health could also cover climate change. ${ }^{98}$ Proof of the measure's contribution towards tackling climate change through preventing carbon leakage would not be enough because it is likely that some evidence of the contribution of the measure to the protection of human, animal or plant life or health specifically is also required. ${ }^{99}$ This does not seem to pose a real problem though, as there is abundant evidence of the detrimental effects of climate change on, for example, biodiversity.

That being said, what the necessity test of paragraph (b) ultimately requires is the balancing of the environmental objective pursued and the contribution of the measure to that objective, on the one hand, with the restrictions on trade, on the other. ${ }^{100}$ Although mitigating climate change would certainly represent an important objective thus lowering the standard of proof - some tangible evidence of how the measure contributes to this objective must always be put forward. This means, in this case, that it will have to be shown both that the free allocation of allowances contributes to

96 Competitiveness claims, based on the disadvantage or cost ensuing from participation in the ETS, do not seem to be directly relevant under Art. XX GATT. Similarly, political considerations do not easily find space in the assessment.

97 It should be noted that measures addressing carbon leakage cannot be held to be extraterritorial and thus raise issues of availability of the Art. XX defence. It is in the nature of GHG emissions that, although produced locally, their effects are felt everywhere.

98 Appellate Body Report, Brazil-Measures Affecting the Imports of Retreated Tyres (Brazil-Retreated Tyres), W/DS332/AB/R, adopted on 17 Dec. 2007, para. 151.

99 See Panel Report, Measures Affecting the Imports of Retreated Tyres (Brazil - Retreated Tyres), W/DS332/R, adopted on 17 Dec. 2007, para. 7.46, in which it is noted that a party invoking an environmental justification under Art. XX(b) GATT 'has to establish the existence not just of risks to "the environment" generally, but specifically of risks to animal or plant life or health'.

100 The current interpretation of the necessity test is a 'weighing and balancing exercise' where a considerable degree of deference is given to Members, particularly with respect to the level of protection decided: see Appellate Body, Brazil-Retreated Tyres, n. 98 above, para. 178. 
preventing carbon leakage, and that preventing leakage indeed contributes to addressing climate change. Crucially, the Appellate Body has acknowledged that the contribution of certain environmental measures, like climate change measures that often operate within a comprehensive set of policy actions, cannot be evaluated in the short term, but only with the 'benefit of time'. ${ }^{101}$ Further, a key point of the necessity test analysis is also the determination of whether less trade-restrictive alternatives to achieve the same aim are available, but, importantly, these should be reasonably available, a qualification that adds to the deference to the country adopting the measure.

Even assuming that the country at issue aims for a very high level of environmental protection, it is clear that both the case of carbon leakage and the contribution of free allowances to addressing it should be properly substantiated. We recall, however, from the economic analysis above, that there is no strong evidence to support claims of carbon leakage. Further, the extent to which preventing carbon leakage contributes to mitigating climate change is not apparent. Carbon leakage will never completely offset the emissions reductions achieved by the emissions trading scheme. Moreover, and more generally, a global restructuring of production might be necessary to mitigate climate change in the most effective manner, and such restructuring would entail carbon leakage.

It should further be taken into account that, by reducing the effective cost of carbon below the market price, the free allocation of allowances may reduce leakage risks but, at the same time, may paradoxically reduce the incentive to abate emissions. ${ }^{102}$ This effect casts doubt on the rationality of free allocation of allowances inasmuch as it ultimately undermines the key goal of the ETS of which they are an integral part.

Although the 'relating to' test is lower than the 'necessity' test, ${ }^{103}$ broadly analogous considerations can be made if the paragraph $(\mathrm{g})$ exception is considered. ${ }^{104}$

\section{The chapean of Article XX GATT}

Assuming the applicability of one of the exceptions and following the two-tier approach set out in US - Gasoline, the objectives of the measure are not only considered in the first step of the analysis of Article XX of the GATT, but also in the second step where the measure's application is considered under the chapeau. The chapeau requires an analysis of the 'causes and the rationale of the discrimination' ${ }^{105}$ A measure may ultimately be justified only if it is applied in line with its legitimate objective.

\footnotetext{
101 Ibid.

102 This may happen in systems with intensity-based or output-based caps alike. See Part 2 above.

103 See Appellate Body Report, United States - Import Prohibition of Shrimp and Certain Shrimp Products (US - Shrimp), WT/DS58/AB/R, adopted on 6 Nov. 1998, para. 141 for the 'relating to' language.

104 Importantly, the Appellate Body in US - Gasoline (n. 91 above, at p. 18) concluded that clean air can be protected under this exception.

105 Appellate Body, Brazil - Retreated Tyres, n. 98 above, para. 225.
} 
What the chapeau proscribes is arbitrary and unjustifiable discrimination with regard to how the measure is applied, not discrimination per se (which, as the Appellate Body recently noted, is already assessed at the level of the exceptions). ${ }^{106}$ Further, this discrimination should be established between countries where the same conditions prevail', not only between different exporting countries but also between importing and exporting countries.

Importantly, the Appellate Body has established that the phrases 'arbitrary discrimination', 'unjustifiable discrimination' and a 'disguised restriction on international trade' impart meaning to one another and serve the same purpose of preventing abuse and illegitimate use of the exceptions. ${ }^{107}$ For the current analysis, this means that these phrases and their consistency with the measure at issue do not have to be discussed separately.

Case law offers more concrete criteria to assess whether the application of a measure is in line with the chapeau. Three important 'groups' of criteria will be discussed here. Firstly, the Appellate Body has stressed the importance of applying a measure that allows for an inquiry into its appropriateness regarding the conditions prevailing in exporting countries. ${ }^{108}$ As such, it is crucial that a measure provides flexibility, by accepting comparable measures abroad as a basis for exempting countries from the application of the trade-restrictive measure. ${ }^{109}$ Secondly, the requirements of 'due process' and fairness have been taken into account under the chapeau. ${ }^{110}$ It is important that, in the application of the measure, decisions are taken with the use of objective and transparent criteria. ${ }^{111}$ Thirdly, to comply with the chapeau, it is vital that the means of international cooperation are adequately explored and good faith efforts have been made to negotiate an international agreement. ${ }^{112}$

The phrase 'between countries where the same conditions prevail' can be of great importance in the context of climate change measures, as shown by the following two examples. Firstly, there is a question of whether the notion of 'prevailing' conditions is in conflict with the UNFCCC ${ }^{113}$ principle of common but differentiated responsibilities that allows different reduction commitments, and thus different treatments on the basis of historical - not prevailing - conditions. The second example relates to the need to provide flexibility in the application of a measure, as established by case law. In the application of the measure, it is important to ensure that it is not 'closed'

106 Appellate Body Report, Thailand - Customs and Fiscal Measures on Cigarettes from the Philippines (Thai-Cigarettes), W/DS371/AB/R, adopted on 15 July 2011, para. 177, which (in the context of item (d) of Art. XX GATT) noted that what has to be necessary is the 'differential treatment' of the measure.

107 Appellate Body, US - Gasoline, n. 91 above, at pp. 22-3.

108 Appellate Body, US - Shrimp, n. 103 above, para. 165.

109 Appellate Body Report, United States - Import Prohibition of Shrimp and Certain Shrimp Products (Article 21.5 DSU) (US - Shrimp 21.5), WT/DS58/AB/RW, adopted on 21 Nov. 2001, para. 144.

110 See, e.g., Appellate Body, US - Shrimp, n. 103 above, paras. 180-1.

111 Panel Report, European Communities - Conditions for the Granting of Tariff Preferences to Developing Countries (EC - Tariff Preferences), WT/DS246/R, adopted on 20 Apr. 2004, paras. 7.228-7.229.

112 See Appellate Body, US - Gasoline, n. 91 above, at p. 29; and Appellate Body, US - Shrimp 21.5, n. 109 above, paras. $132-4$.

113 N. 46 above. 
but is instead 'open' to comparable policy measures of other countries, one of the main lessons of the US - Shrimp litigation. ${ }^{114}$ In the case of emissions trading schemes, it is key to ensure a transparent, non-discriminatory and well-designed 'linking' with other schemes, or, in their absence, with other policy measures that aim to achieve the same objective of emissions reduction. The legality of various national climate policy measures may eventually depend on this. The practical difficulties in determining and comparing the effectiveness of different regulatory systems and tools may be considerable, but attempts towards this end need to be made. Good faith efforts and practical cooperation between countries in this respect may constitute an additional factual element helping to ensure the WTO consistency of the measure and, more radically, may contribute to creating a positive international environment for ongoing efforts to respond to the climate change challenge.

The fact that the EU ETS legislation limits the possibility of concluding linking agreements with countries listed in Annex B of the Kyoto Protocol that have ratified the Protocol ${ }^{115}$ could impede a justification under Article XX of the GATT. The chapeau clearly requires equal treatment in the application of the measure of countries 'where the same conditions prevail'. On the other hand, failure to ratify the Kyoto Protocol, the most important international climate change agreement, is a significant legal, political and environmental condition that could ultimately allow a difference in treatment. The limitation, which excludes those countries that have not ratified the Kyoto Protocol, is intended to exercise political pressure on them to do so. ${ }^{116}$

Bhagwati and Mavroidis have noted the possible relevance of the principle established by the Appellate Body in EC - Tariff Preferences, ${ }^{117}$ though this did not concern the chapeau discussion directly. ${ }^{118}$ In this case, the granting by the EU (then European Communities - EC) of preferences to developing countries was conditioned on the adoption of anti-drug production policies. The Appellate Body concluded that discriminatory preferences are WTO consistent if they are based on 'objective criteria'. Applying this argument in the context of climate change, the signing of the Kyoto Protocol may well be considered to be an objective criterion to discriminate between countries. At the same time, however, simple reliance on the signing of an international agreement - without considering the policy measures adopted at the domestic level - may be unreasonable. If there is an emissions trading scheme that could be linked to the EU ETS, then this other country is, irrespective of any international commitment, undertaking climate change measures. Excluding such a country from

114 It has been noted that this introduces in the chapeau of Art. XX GATT 'an "embryonic" and "soft" requirement on Members to recognize the equivalence of foreign measures comparable in effectiveness': see Van den Bossche, n. 88 above, at p. 645; G. Marceau \& J.P. Trachtmann 'A Map of the WTO Law of Domestic Regulations of Goods', in G.A. Bermann \& P.C. Mavroidis (eds.), Trade and Human Health and Safety (Cambridge University Press: 2006), pp. 9-76, at 42.

115 Art. 25 of Directive 2003/87/EC, n. 82 above.

116 R. Howse \& A.L. Eliason, 'Domestic and International Strategies to Address Climate Change: An Overview of the WTO Legal Issues', in Cottier, Nartova \& Bigdeli, n. 60 above, at pp. 48-94, at 58.

117 Appellate Body Report, European Communities - Conditions for the Granting of Tariff Preferences to Developing Countries (EC -Tariff Preferences), WT/DS246/AB/R, adopted on 20 Apr. 2004. 
the EU ETS would not seem to be justifiable. ${ }^{119}$ This would not make any environmental sense; neither, under the chapeau of Article XX of the GATT, would it make sense from a trade law perspective.

Even though linking an emissions trading scheme is indeed a way of recognizing foreign climate change mitigation efforts, the important question remains whether the free allocation of allowances specifically also takes into account foreign mitigation efforts. The problem is that free allowances can be allocated only to those installations participating in the emissions trading scheme. Consideration of comparable efforts is further restricted by the fact that, in contrast to border measures (which can selectively target the exports from highly emitting economies and sectors), it would be more difficult to shield firms in foreign countries from the effects of subsidies like free allowances on the basis of their mitigation efforts and resulting carbon prices. In this sense, it could be very difficult for a country to bring the allocation of free allowances in line with the chapeau of Article XX.

Additionally, in order for a validation under the chapeau to be possible, it is important that allowances are not allocated for free without an inquiry into other ways of tackling carbon leakage through the means of international negotiations and cooperation. In other words, automatically resorting to free allocation without showing any attention to the broader picture of international policy and discussions with trading partners on the issue may lead to the conclusion that the differential treatment inherent in subsidization is arbitrary and not justified. Lastly, it would be important that the criteria used to determine the beneficiaries of the free allocation of allowances, and those used to determine the amount of allowances allocated free of charge, are transparent and objectively applied.

In conclusion, the case that free allowances could be justified by Article XX of the GATT is tenuous. As the economic analysis shows, the free allocation of allowances does not emerge as instrumental to reducing GHG emissions and tackling carbon leakage. This substantially means that, from a legal perspective, it is difficult to consider them as 'necessary', or even 'related to' these important objectives. Allocating allowances for free does not seem to be justifiable from the environmental viewpoint, which is the one taken by Article XX. Further, even if grounded, competitiveness concerns, or political reasons linked to increasing the acceptability of ETSs, cannot find any shelter under the exceptions of Article XX of the GATT.

\subsection{Looking into the Future: A New Justification?}

The preceding analysis reveals that the allocation of allowances free of charge is not only legally controversial but also environmentally and economically questionable.

119 This seems indeed the rationale of the newly introduced Art. 25.1a of Directive 2003/87/EC, n. 82 above, which allows for agreements on the recognition of allowances of 'compatible mandatory greenhouse gas emissions trading systems with absolute emissions caps established in any other country or in sub-federal or regional entities'. What remains to be seen is whether this amendment eliminates possible claims of bias. One factor that could lead to controversy is the limitation of the linking to ETSs with absolute caps only. 
To be sure, empirical evidence may emerge to support their desirability towards the goal of mitigating climate change. For now, however, it seems to be mainly a political economy argument that provides support for this practice. Undoubtedly, pending the quest for a global solution, ${ }^{120}$ the economic value of free allocation may be a useful bargaining chip to win the consensus of reluctant industries in the adoption of an ETS (being one of the less troublesome unilateral actions to mitigate climate change) and, thus, accommodate any real or alleged competitiveness risks.

Even accounting for this political benefit, the questionable economic and environmental merit of free allocations indicates that, should the path of law reform be followed, attempts to structure a legal shelter for acceptable forms of free allowances should be narrowly constrained and temporary.

In this regard, various circumstances shaping both the approach to and the content of the justification should be considered. Firstly, the competitiveness and carbon leakage concerns that are behind the allocation of allowances free of charge are, to a large extent, dubious and are not currently supported by strong empirical evidence. Secondly, free allocation clashes with important environmental policy principles, such as the 'polluter pays principle', and causes undesirable effects like windfall profits. Further, it may inhibit the incentives of an emissions trading scheme to function as efficiently as they would if allowances were charged.

In the light of these circumstances, the following principles may inform a prospective legal justification:

(a) an express statement that auctioning is the rule and free allocation the exception should be included. This important affirmation would guide the interpretation of the specific conditions of the justification and would further constitute a significant benchmark in determining the existence of a subsidy in the first place;

(b) the balance underlying the justification and its conditions should be informed by the principle of sustainable development, as included in the Preamble to the WTO Agreement. This would, for example, require that the design and application of the measure are such as to effectively create incentives to reduce GHG emissions. Moreover, it would require the legal justification to be aligned with the fundamental policy criterion that the polluter should pay and with the environmental objective of ETS mechanisms, namely, the reduction of GHG emissions; and

(c) given their exceptional character, the justifications should be temporary and carefully designed. The timing and modalities for the phasing-out of the free allocation should be clearly set. In addition, the justifications for free allocation (carbon leakage and distortions in competitiveness) should materialize in specific provisions, providing or requiring plausible proof in terms of harm or threat of harm to the domestic industry or the environment.

120 For some suggestions, see G.C. Hufbauer, S. Charnovitz \& J. Kim, Global Warming and the World Trading System (Peterson Institute of International Economics, 2009); P. Aerni et al., 'Climate Change, Human Rights and International Economic Law: Exploring the Linkages between Human Rights, Trade and Investment' (2010) 53 German Yearbook of International Law, pp. 139-88. 


\section{SOME CONCLUSIONS}

Although more empirical analysis of the impact of ETSs and free allowances is necessary, it is fair to conclude that the allocation of free allowances is problematic from an environmental, economic and legal perspective. Their environmental effectiveness is unclear. In fact, free allowances risk reducing the environmental benefits of an ETS. Further, there are doubts as to whether they have an impact on competitiveness and leakage. In this article, we have focused mainly on the question of whether allocating emissions allowances free of charge could constitute a subsidy. The economic and legal analyses have both shown that this is a distinct possibility, and international trade and competition may be harmed by such a practice. For this reason, there is substantial scope to treat free allowances as subsidies that are objectionable under WTO subsidy rules.

At the same time, however, ETSs can be important tools for mitigating carbon emissions, and including features to avoid carbon leakage may be rational from an environmental and economic perspective. ETSs are becoming increasingly common, and with them the allocation of allowances free of charge. Even assuming that leakage risk is not substantial, or that free allowances are not instrumental in reducing this risk, the practice of distributing allowances free of charge has many advantages. It is acceptable to the concerned industry, it does not impose direct costs on the government, and it is not as provocative to third countries as other options to address carbon leakage or competitiveness concerns. Such measures may be necessary in order for countries to move ahead with unilateral action to mitigate climate change, which, in the absence of a global policy framework, is indeed desirable. As the current row on the extension of the EU ETS to international aviation shows, unilateral action naturally raises frictions. ${ }^{121}$ This supports the argument that those that are less contentious, like free allowances, should be supported.

In this context, important political choices are to be made. Should the ETS be reformed to fit conventional trade imperatives, or should trade law be rethought to be responsive to contemporary environmental protection strategies? It might be worthwhile to consider developing a best practice of emissions trading schemes and, in particular, of free allowances in order to draw lessons from the recent experiences and to optimize the benefits for sustainable development and climate change mitigation, while reducing the potential negative impact on trade. From a trade law perspective, there is also a good case to provide a legal shelter for otherwise objectionable free allowances. In this regard, it has been noted recently how the status quo favours complainants, and 'distributive justice between Members is likely to be skewed in favour of the complaining Member'. ${ }^{122}$ In the absence of specific subsidy justifications, Article XX of the GATT is a tenuous and certainly troublesome route of justification. Law reform appears to be the only alternative. In the light of the

\footnotetext{
121 See 'Opponents of EU Aviation Carbon Law Agree on Possible Countermeasures' (2012) 16(7) Bridges Weekly Trade News Digest, pp. 1-2; A. Hertogen, 'Sovereignty as Decisional Independence over Domestic Affairs: The Dispute on Aviation in the EU Emissions Trading System' (2012) 1(2) Transnational Environmental Law, pp. 281-301. 
questionable economic and environmental merit of free allocation, however, any attempt to legally structure acceptable forms of free of charge allowances should be narrowly constrained and temporary.

Analyzing the question of whether the allocation of allowances free of charge constitutes a subsidy outlines some of the features of contemporary problems in climate change governance. Firstly, complex challenges like climate change rely on the choice and synergy of policy measures the effectiveness of which is often difficult to test because of their novelty and the paucity of empirical data. Secondly, the policy justifications for these measures are various, not always fully grounded, and sometimes in contradiction with each other. Thirdly, global problems like climate change need to be addressed at various levels, and the multi-level responses need to be connected with each other. The regulation of emissions allowances can be found at domestic, regional and international levels. For this reason, the question of whether the free allocation of allowances is efficient and legal, or rather distorting and questionable from a WTO perspective, ultimately interrogates, from an economic, environmental and trade standpoint, how different systems interact with each other. Fourthly, the novelty and complexity of the issues test prevailing tools and rules to their limit, raising intricate questions of interpretation and exposing deficiencies which highlight the need for dialogue that explores a common understanding of the needs and priorities of trade rules with respect to climate change. 